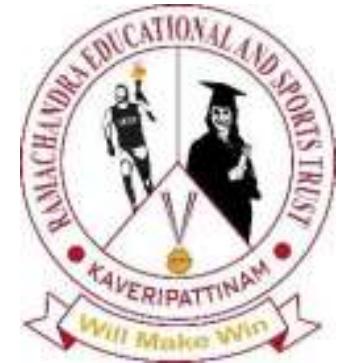

\title{
Recent Trends in Management and Commerce
} Vol:2(2),2021

REST Publisher

ISBN:978-81-936097-6-7

\author{
Website:http://restpublisher.com/book-series/rmc/
}

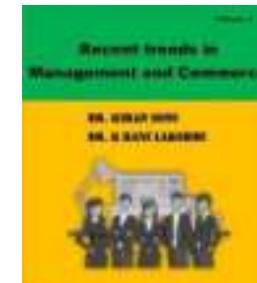

\section{Effect of Marketing Mix Elements on Brand Awareness of Consumer Durables}

M.Sailakshmi

Shri Shankarlal Sundarbai Shasun Jain College for women, Chennai, Tamil Nadu, India.

Email: sailakshmi1926@gmail.com

\begin{abstract}
The Indian economy has transformed from a controlled economy to a market driven economy in recent years. Enormous growth has been witnessed due to an active participation by the private enterprise. Along with other sectors, the consumer durables sector has also been riding a crest of the growth wave in India. Growing awareness, rising income and changing lifestyles have been the key growth drivers of the durables market. The transformed marketing scenario has created a spurt in new business opportunities. Increasing competition, evolving technologies and government policy initiatives including tax reforms have been enabling organizations to maintain a marketing oriented focus with emphasis on creating awareness and ensuring consumer satisfaction. While developing a business plan, an organization focuses on elements of marketing mix, commonly referred to as Ps of marketing, to devise integrated programs and to create a desired response in the targeted market. Marketing communication is devised accordingly to build confidence in consumers about a particular brand. Awareness of a brand affects the mind of a consumer in purchase process and increases the probability of it being selected from a set of alternatives. In the present research, the effect of marketing mix elements on brand awareness and consumer satisfaction in the context of consumer durables sector in the state of Punjab and union territory of Chandigarh has been explored. Four Ps of marketing mix, namely, product, price, promotion, place and two levels of brand awareness, viz., brand recognition and brand recall have been studied. The study assumes significance because not many studies have been conducted to examine such an impact. The effect of elements of marketing mix on consumer satisfaction has also been explored, directly as well as, through brand awareness. xi The scope of consumer durable market has been confined to four brands, namely, air conditioners, refrigerators, washing machines and televisions whose buyers have been selected as respondents. Four brands namely, LG, Samsung, Voltas and Hitachi have been studied in the product category of air conditioners; LG, Samsung, Whirlpool and Godrej in case of refrigerators; LG, Samsung, Whirlpool and Videocon in the category of washing machines; and Sony, LG, Samsung and Videocon in the televisions' category. A pre-tested, structured and non-disguised questionnaire has been used to gather data from 350 consumers. A Likert type scale has been predominantly used. Statistical tools like regression, mediation analysis, and structural equation modeling, and kruskalwallis, t-test and chi-square analysis have been applied.
\end{abstract}

\section{Introduction}

According to Mazur (1947), marketing is formulating and delivering a basic standard of living to the society. It emphasizes the primary functions of marketing, namely, fulfilling social demand for material goods/services and satisfying consumers. Drucker (1975) has emphasized that marketing is recognized as the most important activity in any society because it leads to contentment of human needs and desires by facilitating a continuous supply of goods/services to consumers. It strengthens the economic progress of a country as it opens up new vistas of research by supporting product innovation and enhancing the quality of life for the ultimate consumer (Wilkie and Moore, 1999).RESEARCH OBJECTIVES. The research objectives of this study are:-1. To examine the effect of marketing mix elements on brand awareness. 2. To explore the relationship between marketing mix elements and consumer satisfaction. 3. To analyze the relationship between marketing mix elements and consumer satisfaction through brand awareness.

\section{Research Methodology}

PHASES OF RESEARCH Phase I: Understanding the existing perspective. Existing literature on marketing mix and brand awareness in different contexts has been explored in this phase. The literature includes relationship of elements of marketing mix with brand equity, brand loyalty, brand preferences, brand awareness and consumer satisfaction. It has been reviewed thoroughly to understand the impact of marketing mix on various dimensions of brand equity and consumer satisfaction. Simultaneously, identification and analysis of the variables have been done in this phase.Phase II: Assessment of consumers' perspective. This phase of research involves designing of a well-structured questionnaire to assess the impact of 4Ps on brand awareness of consumers and their satisfaction while purchasing consumer durables. It lays emphasis on brands recently purchased, effect of influencers on decision-making, point of purchase opted, mode of payment chosen and demographic profile of respondents. The questionnaire has been designed after extensive literature review and validated through discussions with academicians and industry experts.Phase III: Pilot testing of study instrumentThe third phase of research pertains to pilot testing of study instrument before its use for final data collection. It has helped in modifying the questionnaire usefully. Validity and reliability of the instrument have been tested on a sample 
of 60 respondents. Data has been collected by administering the questionnaires to the consumers. The respondents have been approached personally in various districts. They have been explained the purpose of questionnaire and help has been extended to them, wherever required, for filling the questionnaire. The consumers have also been assured anonymity and that the requirement of information is for academic purposes only. After collecting the data, values of factor loadings for each statement and Cronbach's alpha for the main constructs have been recorded.Phase IV: Developing a strategic framework. In the last phase of present study, an endeavor has been made to study the impact of elements of marketing mix on brand awareness and also on consumer satisfaction in the context of consumer durables sector. A framework representing the effect of elements of marketing mix on consumer satisfaction through brand awareness has been proposed. Primary data has been collected and analyzed with the help of SPSS (20.0) and AMOS (20.0). Outcomes have been presented.

\section{Review of Literature}

According to Hauser and Wernerfeldt (1990), advertising plays a significant part in generating brand awareness. It has a positive effect on perceived quality and subsequently brand equity. Advertisements also have a positive and a significant effect on brand loyalty as they help in reinforcing brand awareness and steering viewpoints towards a brand. Repetitive advertising programs increase the chances of getting attention for a brand, simplify selection of a consumer and habituate the selection of a brand.Aaker (1991) has emphasized that brand name is one of the imperative factors in brand awareness. The brand is like a file cabinet in consumer's mind and it can be recorded with related names, facts or feelings. Therefore, the author has recommended that a company should focus to connect to attributes, characteristics or names which are important according to a consumer in its marketing communications.Aaker (1991) has suggested that brand awareness linked with strong associations helps in forming a positive image of a brand. Brand associations comprise of numerous instances, Page | 30 ideas, facts and episodes which form a strong network of brand knowledge. Brand associations that result in high awareness of the brand have a significant influence on brand equity. According to author, strong brand associations are based on multiple encounters or repeated exposures to its messages. Such associations are a signal of high quality and pure commitment. It helps a customer to consider a particular brand at time of purchase, which leads to a positive and favorable attitude towards the brand. Odds, Monroe and Grewal (1991) have observed that price has a significant impact on perceived quality, but does not have a significant impact on willingness to buy and perceived value. Store information and positive image of brand have a significant effect on perceived value and quality as well as consumer's intention to buy. Price can be an indicator of the amount of sacrifice which is required for buying a product and also an indicator of the quality level. High price often leads to high level of perceived quality. At the same time, high price also represents a monetary measure of what must be sacrificed in order to purchase the good, which leads to a reduced willingness to buy.

\section{Research Hypothesis}

H1 (a): Marketing mix elements positively affect brand awareness.H2 (a): Marketing mix elements positively affect consumer satisfaction. H3 (a): Marketing mix elements have an indirect effect on consumer satisfaction through brand awareness.Aaker (1991) has identified brand recognition and brand recall as levels of brand awareness. Percy and Rossiter (1992) have classified brand recognition and brand recall as types of brand awareness. Therefore, the following two hypotheses have been framed additionally. H3 (b): Marketing mix elements have an indirect effect on consumer satisfaction through brand recognition. H3 (c): Marketing mix elements have an indirect effect on consumer satisfaction through brand recall.

\section{Summary of Findings}

A review of literature followed by findings of the present study have yielded insights into a number of important aspects of marketing like product and store attributes influencing consumers' choices, pricing tactics encouraging purchase decisions, promotional strategies to create brand awareness, amongst other aspects. Though some studies have already been conducted in India to cover different aspects of marketing mix and brand awareness, the present study attempts to present a comprehensive view from consumers' perspective. It focusses on the effect of elements of marketing mix on brand awareness levels and satisfaction levels of consumers. It analyses the relationship between elements of marketing mix and consumer satisfaction in the light of brand awareness. It also examines the level of brand awareness and consumer satisfaction, with respect to demographic variables. The impact of influencers on decision-making of consumers, level of success in creating brand awareness, choice of point of purchase and mode of payment have also been discussed.

\section{Conclusions}

This chapter comprises the summary of results. It discusses various research objectives with respect to findings of the study. It presents the theoretical discussion, implications, contributions and limitations of the present research. Recommendations for future research directions have also been highlighted.

\section{References}

1. Aaker, D. A. (1990). Consumer evaluations of brand extensions. Journal of Marketing, 54 (1), 27-41.

2. Aaker, D. A. (1991). Managing brand equity: capitalizing on the value of a brand name. New York, N.Y: The Free Press.

3. Aaker, D. A. (1996). Measuring brand equity across products and markets. California Management Review, 38(3), 102-120.

4. Aaker, D.A., \& Álvarez del Blanco, R.M. (1995). Stature of the brand: measuring the value by products and markets. Harvard-Deusto Business Review, 69 (nov-dec), 74-87.

5. Aaker, D., \& Keller, K. (1990). Consumer evaluations of brand extensions. Journal of Marketing, 54(January), 2741 